\title{
Application of Illite- and Kaolinite-Rich Clays in the Synthesis of Zeolites for Wastewater Treatment
}

\author{
Carlos Alberto Ríos Reyes ${ }^{1}$ and Luz Yolanda Vargas Fiallo² \\ ${ }^{1}$ School of Geology, Universidad Industrial de Santander \\ ${ }^{2}$ School of Chemistry, Universidad Industrial de Santander \\ Colombia
}

\section{Introduction}

Water is the source of life and is the basic condition of human survival. However, the severe water contamination and insufficient water source are nowadays two thorny problems. Industrial effluents are contaminated with highly toxic, non-biodegradble and cancerogenic heavy metals, which are generated by industries such as electroplating, mineral processing, galvanization plants, paints formulation, porcelain enameling, nonferrous metal and vegetable fat producing industries (Meena et al., 2005). Due to the discharge of large amounts of metal-contaminated wastewater, the electroplating industry is one of the most hazardous among the chemical-intensive industries (Pereira et al., 2010). If not carefully managed, however, wastewater may produce both short- and long-term effects on human health and the ecological system. In many developing countries there are deadly consequences associated with exposure to contaminated water, as many developing countries have increasing population densities, increasingly scarce water resources, and no water treatment utilities. Therefore, there are huge challenges all over the world regarding the handling of waste water for a sustainable future.

The processes of dissolution, transport and immobilization of heavy metal ions are very important in environmental science and technology. Many industrial processes involve solubilisation of heavy metal ions to aqueous solutions which then are released into the environment via wastewater; as heavy metal ions persist in the environment, an effective protection strategy requires the ions to be sequestered from the wastewater (Nestle, 2002). Several treatment technologies for wastewater treatment, including chemical precipitation, electrodeposition, ion exchange, membrane separation and adsorption, have been developed (Diz \& Novak, 1998; Webster et al., 1998; Feng et al., 2000; Mohan \& Chander, 2006; Chartrand \& Bunce, 2003; Santos et al., 2004; Gibert et al., 2005; Johnson \& Hallberg, 2005; Wattena et al., 2005; Wei et al., 2005; Kalin et al., 2006; Ríos et al., 2008), although adsorption has been the preferred method for heavy metal removal, because it is considered to be a particularly effective technique if it takes in consideration the use of suitable, cheap, and environmentally friendly sorbent materials. Heavy metal removal from electroplating wastewater have been investigated by several researchers (Algara et al., 2005; Sousa et al., 2009). Adsorption is usually quite a complex process, generally involving much more than 
simple ion exchange into the pore openings of the ion exchanger. Factors such as $\mathrm{pH}$, nature and concentration of the counter ion (metal ion), ion hydration, varying metal solubilities, presence of competing and complexing ions, all affect the amount of metal ion to be adsorbed (Ikhsan et al., 1999) and therefore the sorbent selectivity.

One of the biggest advantages of clays that have to be used as raw materials in the synthesis of zeolites is their relatively low cost, which allows applications to be industrially feasible. Clays, such as clay minerals such as kaolinite (Breck, 1974; Barrer, 1982; Boukadir et al., 2002; Ríos, 2008; Ríos et al., 2009, 2011), halloysite (Klimkiewicz \& Drąg 2004; Zhao et al., 2010), illite (Mezni et al., 2011), montmorillonite (Song \& Guo, 1997; Ruiz et al., 1997; Cañizares et al., 2000; Boukadir et al., 2002), vermiculite (Johnson \& Worrall, 2007), serpentine (Saada et al., 2009) and interstratified illite-smectite (Baccouche et al., 1998), have been used as the $\mathrm{Al}$ and $\mathrm{Si}$ sources for the synthesis of several types of zeolites.

Due to their exceptional properties, zeolites have been widely used as catalysts, adsorbents and ion exchangers (Breck, 1974). Numerous types of adsorbents such as organic and inorganic materials have been tested for their ability to remove heavy metals. Water researchers are seeking cheaper raw materials low-cost sorbents such as clay-based zeolites with application in the uptake of heavy metals from polluted effluents. Such adsorbents would be a viable replacement or supplement to chemicals, although they should be readily available, economically feasible, and should be regenerated with ease. The potential use of clay-based zeolites in the treatment of wastewater has been evaluated by a number of research groups (Bhattacharyya \& Gupta, 2008; Jamil et al., 2010; Ibrahim, 2010).

The aims of this study are to combine two areas of expertise, water science and clay minerals and zeolites chemistry as well as to address the problem of environmental pollution by removal of heavy metal contaminants.

\section{Experimental procedure and materials}

\subsection{Materials}

The natural clays used as starting materials in zeolite synthesis corresponds to illite-rich clay from the Barroblanco mine, situated in the municipality of Oiba (Santander), and kaoliniterich clay cropping out around the Sochagota Lake, Paipa (Boyacá). The raw materials were prepared prior to the synthesis process by drying during $24 \mathrm{~h}$, and pulverized with an agate Mortar grinder RETSCH RM 100. Finally, the samples were sieved and particles of $63 \mu \mathrm{m}$ selected for zeolite synthesis. Activating was done using the following chemical reagents: sodium hydroxide, $\mathrm{NaOH}$, as pellets (99\%, Aldrich) and distilled water. To determine the removal efficiency of $\mathrm{Cr}^{+3}$ and $\mathrm{Ni}^{+2}$ of the as-synthesized zeolite, a wastewater sample was collected from an electroplating industry located at Bucaramanga (Santander).

\subsection{Hydrothermal transformation of clays into zeolites}

The synthesis of faujasite-type zeolite from clays was conducted under hydrothermal conditions. An alkaline fusion step was introduced prior to hydrothermal treatment, because it plays an important role in enhancing the hydrothermal conditions for zeolite synthesis. On the other hand, this approach was adopted in this study because larger amounts of aluminosilicates can be dissolved employing this method. Raw and calcined at 900 oC materials were dry mixed with $\mathrm{NaOH}$ pellets (starting material/alkaline activator $=$ $1 / 1.2$ in weight) for $30 \mathrm{~min}$ and the resultant mixture was fused at $600{ }^{\circ} \mathrm{C}$ for $1 \mathrm{~h}$. The alkaline fused product was ground in a mortar and then $4.40 \mathrm{~g}$ of this was dissolved in 21.50 
$\mathrm{ml}$ of distilled water (ratio $=1 / 4.9$ ) under stirring conditions for $30 \mathrm{~min}$ and then the reaction gel was aged for $24 \mathrm{~h}$ to form the amorphous precursors. The amount of reagents used for the preparation of the hydrogels was based on previous experimental work developed by Ríos and co-workers (Ríos, 2008; Ríos et al., 2009). Crystallization was carried out by hydrothermal synthesis under static conditions in PTFE vessels of $65 \mathrm{ml}$ at $80^{\circ} \mathrm{C}$ for different reaction times $(6,24$ and $96 \mathrm{~h})$. At the end of the process the solid is separated by filtration, washed thoroughly several times with distilled water until the filtrate $\mathrm{pH}$ reduced to less than 10 . The precipitated solid dried at $100^{\circ} \mathrm{C}$ overnight. The dried samples were weighed and kept in plastic bags for characterization.

\subsection{Characterization of the raw materials and as-synthesized zeolites}

Powder X-ray diffraction patterns of the raw materials and as-synthesized products were recorded with a Philips PW1710 diffractometer operating in Bragg-Brentano geometry with $\mathrm{Cu}-\mathrm{Ka}$ radiation $(40 \mathrm{kV}$ and $40 \mathrm{~mA})$ and secondary monochromation. Data collection was carried out in the $2 \theta$ range $3-50^{\circ}$, with a step size of $0.02^{\circ}$. Phase identification was performed by searching the ICDD powder diffraction file database, with the help of JCPDS (Joint Committee on Powder Diffraction Standards) files for inorganic compounds.

\subsection{Sorption tests and water analyses}

Clay-based faujasite was studied in laboratory batch experiments to determine its sorption of $\mathrm{Cr}^{+3}$ and $\mathrm{Ni}^{+2}$, which was carried out at room temperature to investigate the efficiency of the as-synthesized zeolite as sorbent material for removing heavy metals from aqueous solution. A weighted amount of sorbent $(0.25$ and $0.5 \mathrm{~g})$ was introduced in $180 \mathrm{~g}$ amber glass bottles, and then a volume of $50 \mathrm{ml}$ of electroplating industry wastewater was added. Later, the sorbent:aqueous solution mixtures were continuously shaked for $24 \mathrm{~h}$, and the temporal evolution of the solution $\mathrm{pH}$ and electrical conductivity was monitored. At several scheduled reaction times the bottles were removed from the shaker and the adsorbents were separated by filtration, while the filtrates were stored in a refrigerator for chemical analyses. All measurements were done according to the "Standard Methods for the Examination of Water and Wastewater" (APHA, AWWA, WEF, 2005). The $\mathrm{pH}$ and electrical conductivity of the original and treated aqueous solutions were measured using a pH Meter Lab 870 (Schott Instruments) and a 712 conductometer (Metrohm AG), respectively. The metal concentrations were determined using a Perkin-Elmer 372 atomic absorption spectrophotometer. The efficiency of treatment of the electroplating effluent using faujasite was then determined by the following equation:

Metal Removal Efficiency $=\left(\mathrm{C}_{1}-\mathrm{C}_{2}\right) / \mathrm{C}_{1} \times 100$,

Where $C_{1}=$ initial metal concentration and $C_{2}=$ metal concentration after treatment.

\section{From clays to zeolites}

Both clays and zeolites are aluminosilicates, which differ, however, in their crystalline structure. Clays have a layered crystalline structure and are subject to shrinking and swelling as water is absorbed and removed between the layers. Zeolites have a rigid, 3dimensional crystalline structure consisting of a network of interconnected tunnels and cages. Water moves freely in and out of these pores but the zeolite framework remains rigid. Clays are characterized by two-dimensional sheets of corner sharing $\mathrm{SiO}_{4}$ and $\mathrm{AlO}_{4}$ tetrahedra. In these tetrahedral sheets, each tetrahedron shares 3 of its vertex oxygen atoms 
with other tetrahedra forming a hexagonal array in two-dimensions. The fourth vertex is not shared with another tetrahedron and all of the tetrahedra point in the same direction. The tetrahedral sheets are always bonded to octahedral sheets formed from small cations, such as $\mathrm{Al}^{+3}$ or $\mathrm{Mg}^{+2}$, coordinated by six oxygen atoms. The unshared vertex from the tetrahedral sheet also form part of one side of the octahedral sheet but an additional oxygen atom is located above the gap in the tetrahedral sheet at the center of the six tetrahedra. This oxygen atom is bonded to a hydrogen atom forming an $\mathrm{OH}$ group in the clay structure. Clays can be categorized depending on the way that tetrahedral and octahedral sheets are packaged into layers, and they are commonly referred to as 1:1 and 2:1 clays with t-o and t-o-t layers, respectively. A 1:1 clay would consist of one tetrahedral sheet and one octahedral sheet (e.g., kaolinite, Figure 1a). A 2:1 clay consists of an octahedral sheet sandwiched between two tetrahedral sheets (e.g., illite, Figure 1b), which occurs due to two tetrahedral sheets with the unshared vertex of each sheet pointing towards each other and forming each side of the octahedral sheet. The crystal structure is formed from a stack of layers interspaced with the interlayers (spaces between the $\mathrm{t}$-o or t-o-t layer packages). In the kaolinite structure, the layer will be electrically neutral (uncharged) and the t-o layers are bonded together only by weak intermolecular forces (van der Waals' bonds). In the illite structure the layer will have a net negative charge and $\mathrm{K}^{+}$ions will be attached themselves to clay surfaces in the socalled interlayer sites. In each case the interlayers can also contain $\mathrm{H}_{2} \mathrm{O}$ molecules.
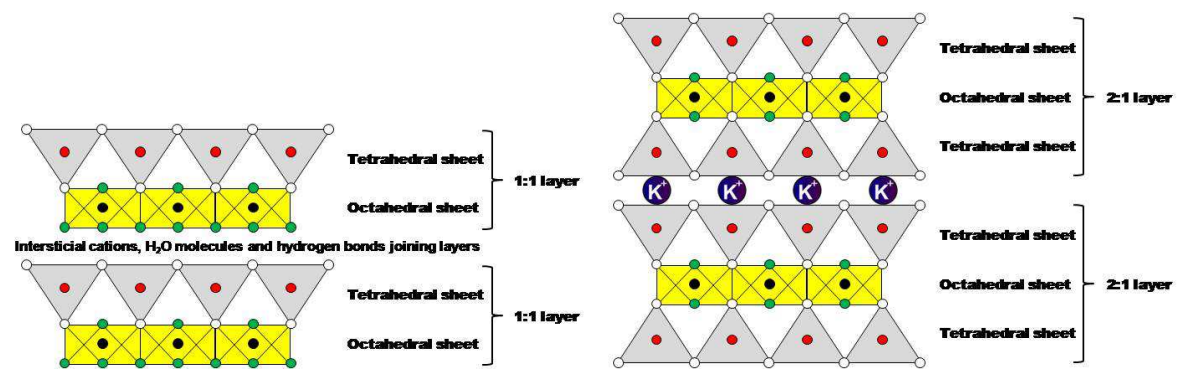

Fig. 1. Diagramatic sketch of the structure of kaolinite and illite.

Zeolites are crystalline, microporous, hydrated aluminosilicates of alkaline or alkaline earth metals with open $3 \mathrm{D}$ framework structures built of $\left[\mathrm{SiO}_{4}\right]^{-4}$ and $\left[\mathrm{AlO}_{4}\right]^{-5}$ tetrahedra linked to each other by sharing all the oxygen atoms to form cages connected by pore openings of defined size, developing a rich variety of beautiful zeolite structures (Breck, 1974; Barrer, 1982; Szostak, 1989), such as the low-silica zeolites Na-X (FAU, faujasite), with a molar ratio of $\mathrm{Si} / \mathrm{Al}$ of 1:1. A polymerization (Figure 2) should be the process that forms the faujasitetype zeolite precursors, which contains tetrahedra of $\mathrm{Si}$ or $\mathrm{Al}$ randomly distributed along polymeric chains that are cross-linked so as to provide cavities sufficiently large to accommodate the charge balancing alkali ions. The faujasite-type zeolite is based on the primary building units $\left(\mathrm{TO}_{4}\right)$ where the central tetrahedrally bonded $(\mathrm{T})$ atom is usually either $\mathrm{Si}^{4+}$ or $\mathrm{Al}^{3+}$, surrounded by four $\mathrm{O}^{-2}$. The primary $\mathrm{TO}_{4}$ units can be linked to create secondary building units. In the faujasite-type zeolite, a combination of 4- and 6-rings promoted the formation of the $\beta$-cage. The secondary building units consist of n-ring structures, with each corner in the secondary building units representing the center of a tetrahedron. Secondary building units can be linked to form cages or channels within the faujasite structure. The aluminosilicate cages and the 6-rings connect to form a three 
dimensional net type structure. The framework of faujasite, consists of sodalite (SOD) cages composed of six 4-rings and eight 6-rings. Therefore, the framework of faujasite consists of $\beta$-cages (SOD) and a-cages (supercages); $\beta$-cages are linked together by double sixmembered rings (D6R) and form the supercages of faujasite, which has a diameter of $13.0 \AA$, is surrounded by $10 \beta$-cages and is interconnected to four other supercages by tetrahedrally disposed 12-membered-ring windows.

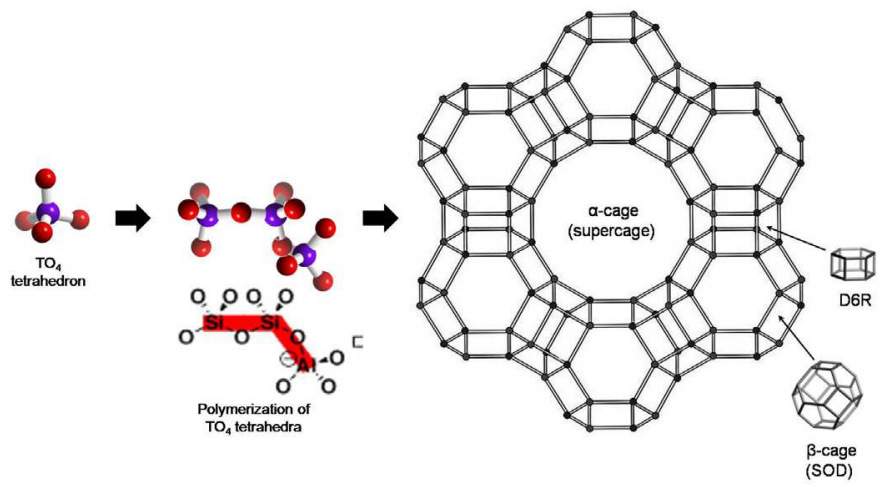

Fig. 2. Framework structure of zeolite $\mathrm{Na}-\mathrm{X}$ (FAU), showing their characteristic cages and channels.

\section{Results}

\subsection{Characterization of the raw clays}

As shown in the XRD pattern of Fig. 3a, illite is the predominant mineral phase in the starting material and is identified by a series of basal reflections at $10.1 \AA$, 4.98-5.01 $\AA$, 3.33 $\AA$, and 2.89-2.92 $\AA$. Similar results have been reported by Mezni et al. (2011). As shown in the XRD pattern of Fig. 3b, kaolinite is the predominant mineral phase, which can be identified by its distinctive reflections at $12.34^{\circ}$ and $24.64^{\circ} 2 \theta$ as reported by Zhao et al. (2004). In both clays quartz was identified by its distinctive reflections at $4.26 \AA$ and $3.35 \AA$. The $3.35 \AA$ A peak of quartz was more intense than the other peaks.
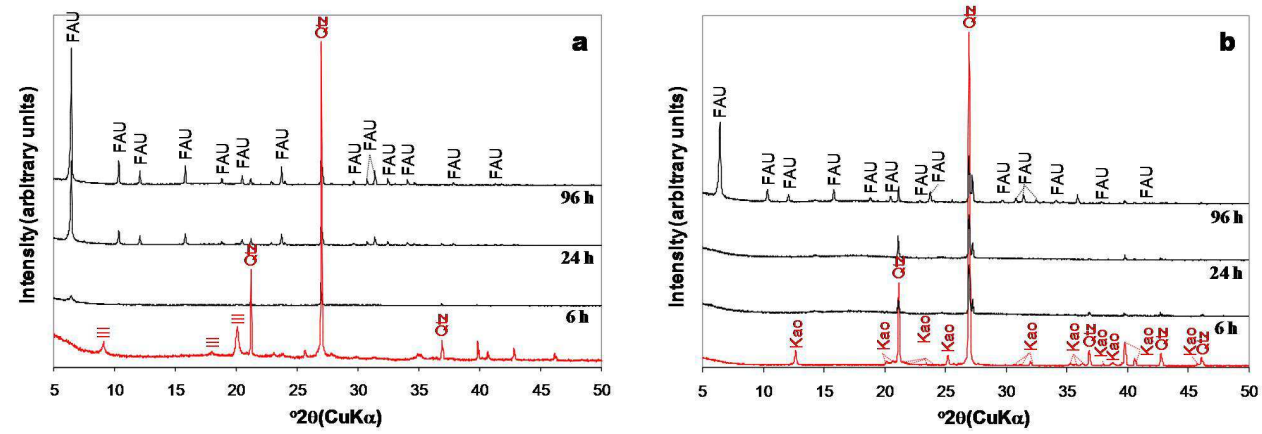

Fig. 3. X-ray diffraction patterns of the raw clays and as-synthesized faujasites. 


\subsection{Characterization of the clay-based faujasites}

As shown in Figure 3, an almost complete transformation of the starting clay-rich materials into faujasite-type zeolite of high purity occurred. However, relictic quartz of the starting materials still remain in the synthesis products. Newly formed compounds dissolved in water more readily than the mineral phases in the starting materials, which have a low velocity of dissolution with the occurrence of some of them as relict phases in the synthesis products. The activation of the starting materials produced a rapid dissolution of the alkaline-fused products only after $6 \mathrm{~h}$ of reaction, and the complete disappearance of characteristic peaks of illite and kaolinite, accompanied by the gradual decrease in peak intensity of quartz that persisted in the products obtained. Moreover, the occurrence of faujasite was recorded after $24 \mathrm{~h}$, showing an increase in the intensity of characteristic peaks between 24 and $96 \mathrm{~h}$. Both samples produced a similar zeolite phase (faujasite), except for the fact that kaolinite-based faujasite showed less intense peaks that illite-based faujasite. Therefore, we decide to use the illite-based faujasite in the sorption tests.

\section{Effectiveness of illite-based zeolites as sorbent material in heavy metal uptake}

\subsection{Kinetics of the neutralization reaction}

The kinetics of the neutralization reaction was investigated by monitoring the $\mathrm{pH}$ and electrical conductivity of faujasite / aqueous solution mixtures $(0.25 \mathrm{~g} / 50 \mathrm{ml}$ and $0.50 \mathrm{~g} / 50$ $\mathrm{ml}$ ) over a period of $24 \mathrm{~h}$. The effect of contact time on $\mathrm{pH}$ and $\mathrm{EC}$ during the sorption experiments for $\mathrm{Cr}^{+3}$ and $\mathrm{Ni}^{+2}$ is shown in Figure 4. Results reveal that the adsorption process of these heavy metals by faujasite was highly $\mathrm{pH}$-dependent and increased with increasing $\mathrm{pH}$ conditions. $\mathrm{pH}$ increased rapidly within the first $5 \mathrm{~min}$ of contact between the solution and the sorbent (illite-based faujasite), and then it thereafter become stable (Figures $4 \mathrm{a}$ and $4 \mathrm{~b}$ ). According to Genç-Fuhrman et al. (2007), $\mathrm{pH}$ increases mainly due to dissolution of the sorbent in the process of shaking. Final $\mathrm{pH}$ values of 7.58-7.69 for $\mathrm{Cr}^{+3}$ and 8.42-8.53 for $\mathrm{Ni}^{+2}$ were observed in the batches. This significantly increased $\mathrm{pH}$ value during the experiments can be explained by the simultaneous uptake of hydrogen ions by faujasite, the hydrolysis of faujasite and the cationic exchange. Similar results are reported elsewhere with a remark that the $\mathrm{pH}$ increase is almost unavoidable in a removal of heavy metals by zeolite, taking into account its alkaline nature. On the other hand, results reveal that there is an increase in $\mathrm{pH}$ with sorbent dosage. A similar behavior was observed for EC as shown in Figures $4 \mathrm{c}$ and $4 \mathrm{~d}$.

\subsection{Uptake of $\mathrm{Cr}^{+3}$ and $\mathrm{Ni}^{+2}$}

Removal of heavy metal ions such as $\mathrm{Cr}^{+3}$ and $\mathrm{Ni}^{+2}$ from electroplating wastewater has been investigated in order to determine the effectiveness of illite-based faujasite as sorbent material in the immobilization of $\mathrm{Cr}^{+3}$ and $\mathrm{Ni}^{+2}$, exploiting the sorption capacity of this zeotype in order to evaluate its potential for the reduction of metal mobility and availability and its possible application for the remediation of wastewater.

The kinetics of adsorption process on porous materials such as zeolites is controlled by three consecutive steps (Mohan et al., 2001; Baniamerian et al., 2009): transport of the adsorbate from the bulk solution to the film surrounding the adsorbent, diffusion from the film to the proper surface of adsorbent, and diffusion from the surface to the internal sites followed by adsorption immobilization on the active sites. 

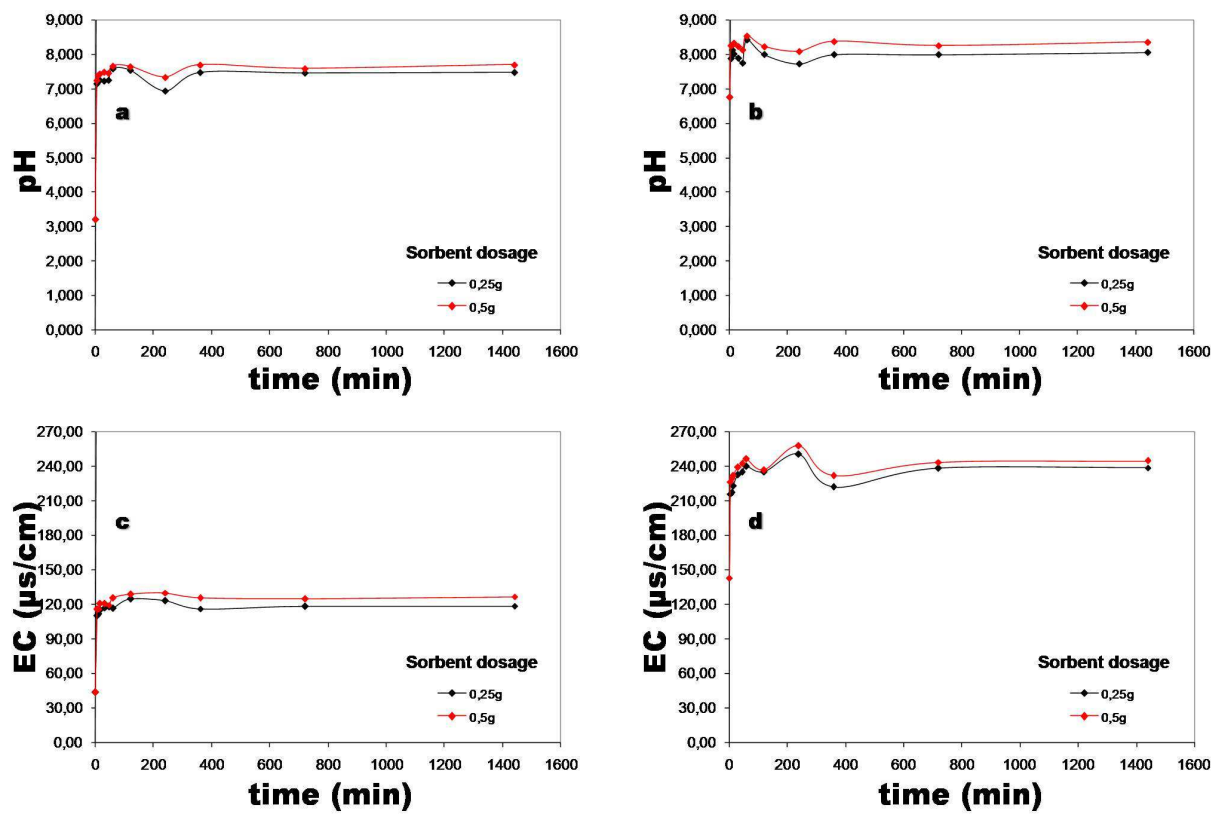

Fig. 4. Variation of $\mathrm{pH}$ and electrical conductivity as a function of time during the sorption tests for $\mathrm{Cr}^{+3}(\mathrm{a}-\mathrm{c})$ and $\mathrm{Ni}^{+2}(\mathrm{~b}-\mathrm{d})$. Starting $\mathrm{pH}$ and $\mathrm{EC}$ of 3.20 and $43.24 \mu \mathrm{S} / \mathrm{cm}$ for $\mathrm{Cr}^{+3}$ and 6.75 and $142.80 \mu \mathrm{S} / \mathrm{cm}$ for $\mathrm{Ni}^{+2}$.

Our study of adsorption kinetics of $\mathrm{Cr}^{+3}$ and $\mathrm{Ni}^{+2}$ ions was performed on faujasite-type zeolite at room temperature over 24 hours. Metal uptake trends as a function of contact time after batch reaction are illustrated in Figure 5. Results indicate that faujasite produced a steep decrease in $\mathrm{Cr}^{+3}$ concentration within the first $5 \mathrm{~min}$, reaching very low residual concentrations. However, after 45 min plateau values were reached for the rest of the time intervals, indicating a complete removal. $\mathrm{Cr}^{+3}$ shows an abrupt decrease in concentration from 0 to $45 \mathrm{~min}$ and tends to stabilize at values between 0,922 and $1,695 \mathrm{mg} / \mathrm{L}(0.25 \mathrm{~g}$ of

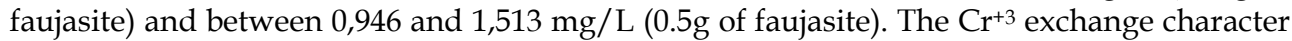
is irreversible. $\mathrm{Ni}^{+2}$ showed an inconsistent variation of concentration between 0 and 360 min, which is revealed by the fluctuations observed during the batch experiments, and tends to stabilize at values between 35,614 and $38,763 \mathrm{mg} / \mathrm{L}(0.25 \mathrm{~g}$ of faujasite) and between 47,963 and $50,184 \mathrm{mg} / \mathrm{L}$ ( $0.5 \mathrm{~g}$ of faujasite). Therefore, a lower sorption of $\mathrm{Ni}^{+2}$ was observed which can be attributed to the higher selectivity to $\mathrm{Cr}^{+3}$ by illite-based faujasite. In general, the adsorption capacity increase as $\mathrm{pH}$ approaches neutral.

Several studies (e.g., Kannan \& Rajakumar, 2003) report the apparent increase of the percentage of removal of heavy metals with increase in the dose of sorbent due to the active sites/surface area for the adsorption of metal ions, whereas, at lower sorbent dosage the number of metal ions was relatively higher, compared to availability of adsorption sites/surface area. However, results from this study reveal that there is not a strong difference in percentage of metal ion removal with sorbent dosage. Therefore, it is clear that it is very important to investigate in future studies the optimum dosage of faujasite-type zeolite tested as sorbent material. 

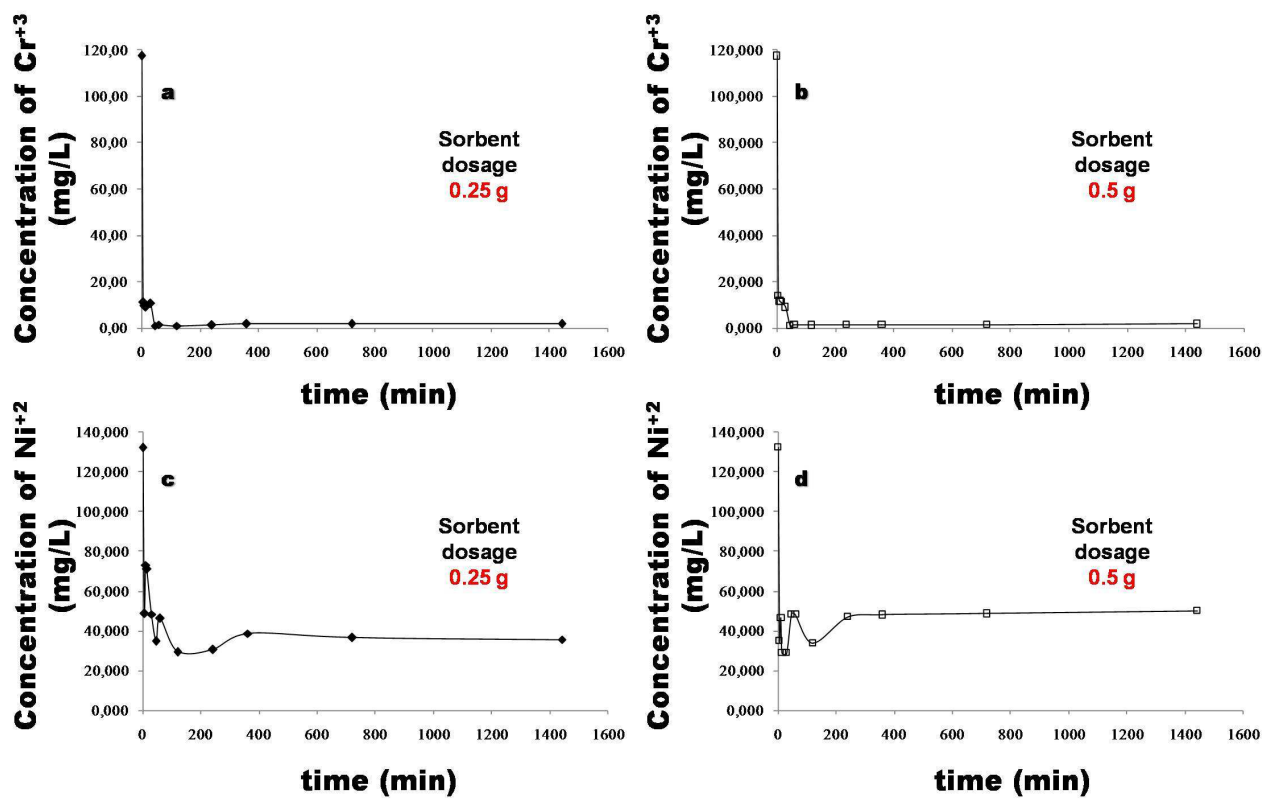

Fig. 5. Variation of concentration of $\mathrm{Cr}^{+3}$ and $\mathrm{Ni}^{+2}$ as a function of time during the sorption batch experiments. Starting concentration $117,300 \mathrm{mg} / \mathrm{L}$ for $\mathrm{Cr}^{+3}$ and $132,300 \mathrm{mg} / \mathrm{L}$ for $\mathrm{Ni}^{+2}$.

According to Jenne (1998), heavy metal cations can be immobilized by zeolites by two mechanisms: ion exchange and chemisorption. Ion exchange involves substitution of ions present in zeolite crystalline lattice by metal ions from the solution (Inglezakis et al., 2002). The type of cation (the position of the cation in the selectivity series) as well as the cation concentration in the solution will determine the ion-exchange efficiency (Mozgawa \& Bajda, 2005). Chemisorption results in the formation of stable inner-sphere complexes (Godelitsas, 1999). This is due to the fact that functional groups (mainly $\mathrm{OH}-$ ) form strong chemical bonds with metal ions outside the hydration envelope (Jenne, 1998).

As reported in previous studies (e.g. Mozgawa \& Bajda, 2005), after zeolite reaches the saturation level of a metal ion sorbed, further $\mathrm{pH}$ lowering causes the increase in the zeolite crystalline lattice positive charge, which reduces the zeolite ability of metal cations chemisorption. The proportion of chemisorption and ion-exchange processes depends on $\mathrm{pH}$ changes and inherent properties of the metal.

The retention efficiency (for the metals considered) depended, not only on the ionic exchange capacity of the as-synthesized zeolite, but also on the decrease of the acidity induced by the zeolitic product. The retention efficiency of faujasite produced the following ranges: $\mathrm{Cr}^{+3}$ (90.53-99.21\%, $0.25 \mathrm{~g}$ of zeolite, and $88.31-99.19 \%, 0.5 \mathrm{~g}$ of zeolite), and $\mathrm{Ni}^{+2}$ (44.74-77.73\%, 0.25 $\mathrm{g}$ of zeolite, and $62.07-78.30 \%, 0.5 \mathrm{~g}$ of zeolite). Sorption tests reveal that both metal ions were rapidly removed by faujasite within $45 \mathrm{~min}\left(\mathrm{Cr}^{+3}\right)$ and $360 \mathrm{~min}\left(\mathrm{Ni}^{+2}\right)$ with $88.31-90.53 \%$ and 63.24-73.54\% of the metal removal achieved in the first $5 \mathrm{~min}$ for $\mathrm{Cr}^{+3}$ and $\mathrm{Ni}^{+2}$, respectively. According to Mozgawa \& Bajda (2005), the contribution of chemisorption and ion-exchange processes to the metal immobilization on zeolite depends on the metal type and the reaction 
time. In the case of $\mathrm{Cr}^{+3}$ and $\mathrm{Ni}^{+2}$, after the first minutes of reaction, it is probably that the chemisorption process becomes more dominant than the ion-exchange process, similar to data reported by Mozgawa \& Bajda (2005). Faujasite-type zeolite produced lower $\mathrm{Ni}^{+2}$ removal (88.31-99.21\%) compared with that for $\mathrm{Cr}^{+3}$ (44.74-78.30\%). However, the competition for sorbent adsorption sites in the presence of $\mathrm{Cr}^{+3}$ produced a decrease in the uptake of $\mathrm{Ni}^{+2}$. No significant adsorption was observed after $45 \mathrm{~min}\left(\mathrm{Cr}^{+3}\right)$ and $360 \mathrm{~min}\left(\mathrm{Ni}^{+2}\right)$ of contact time.

According to Peric et al. (2004), the immobilization of heavy metals from aqueous media is a complex process, which consists of ion exchange and adsorption and is likely to be accompanied by precipitation of metal hydroxide complexes on active sites of the particle surface. On the other hand, the addition of an alkaline material such as faujasite to the electroplating wastewater increased the $\mathrm{pH}$. (7.58-7.69 for $\mathrm{Cr}^{+3}$ and 8.42-8.53 for $\mathrm{Ni}^{+3}$ ) and these metal ions could be hydrolyzed and precipitated as suggested by Evangelou and Zhang (1995). However, the efficiency of the tested sorbent with respect to metal retention and/or metal concentration control during its application for the treatment of metal-bearing aqueous media is governed by parameters like contact time, $\mathrm{pH}$, temperature and sorbent nature as demonstrated in previous studies (Helquet et al., 2000). On the other hand, mechanisms of interactions, such as precipitation and adsorption, between $\mathrm{Cr}^{+3}$ and $\mathrm{Ni}^{+3}$ and illite-based faujasite are strongly influenced by $\mathrm{pH}$.

\section{Conclusions}

Natural clays were successfully transformed into highly crystalline faujasite-type zeolite by fusion with $\mathrm{NaOH}$ powder followed by hydrothermal treatment. The adsorption studies showed rapid uptake in general for the first $45 \mathrm{~min}\left(\mathrm{Cr}^{+3}\right)$ and $360 \mathrm{~min}\left(\mathrm{Ni}^{+2}\right)$ with 88.3190.53\% and 63.24-73.54\% of the metal removal achieved in the first $5 \mathrm{~min}$ for $\mathrm{Cr}^{+3}$ and $\mathrm{Ni}^{+2}$, respectively. After this initial rapid period, the rate of adsorption decreases. The assynthesized faujasite proved to have great potential in the immobilization of $\mathrm{Cr}^{3+}$ and $\mathrm{Ni}^{2+}$ from electroplating wastewater. Results of this work can be also used as a reference for future in depth studies considering alternative technologies applied to remediation of electroplating industry wastewater.

\section{Acknowledgments}

This research forms part of the background experience of the authors in the field of clay and zeolite technology and has benefited from research facilities provided by the Universidad Industrial de Santander, and the Instituto Zuliano de Investigaciones Tecnológicas. We thank to Miguel Ramos for assistance with XRD data acquisition.

\section{References}

Algarra, M.; Jiménez, M.V.; Rodríguez-Castellón, E.; Jiménez-López, A. \& Jiménez-Jiménez, J. (2005). Heavy metals removal from electroplating wastewater by aminopropyl-Si MCM-41. Chemosphere, Vol. 59, No. 6, (May 2005), pp. 779-786, ISSN 0045-6535

American Public Health Association (APHA), American Water Works Association (AWWA), \& Water Environment Federation (WEF). (2005). Standard Methods for the Examination of Water and Wastewater. A.D. Eaton, L.S. Clesceri, E.W. Rice, A.E. Greenberg and M.A.H. Franson (Eds.), 21st Ed., 1368p. 
Baccouche, A.; Srasra, E. \& Maaoui, M.E. (1998). Preparation of Na-P1 and sodalite octahydrate zeolites from interstratified illite-smectite. Applied Clay Science, Vol. 13, No. 4, (October 1998), pp. 255-273, ISSN 0169-1317

Baniamerian, M.J.; Moradi, S.E.; Noori, A. \& Salahi, H. (2009). The effect of surface modification on heavy metal ion removal from water by carbon nanoporous adsorbent. Applied Surface Science, Vol. 256, No. 5, (December 2009), pp. 1347-1354, ISSN 0169-4332

Barrer, R.M. (1982). Hydrothermal Chemistry of Zeolites, Academic Press, ISBN 0120793601, New York, USA

Bhattacharyya, K.G. \& Gupta, S.S. (2008). Adsorption of a few heavy metals on natural and modified kaolinite and montmorillonite: A review. Advances in Colloid and Interface Science, Vol. 140, No. 2, (August 2008), pp. 114-131, ISSN 1359-0294

Boukadir, D.; Bettahar, N. \& Derriche, Z. (2002). Synthesis of zeolites 4A and HS from natural materials. Annales de Chimie Science des Matériaux, Vol. 27, No. 4, (July 2002), pp. 1-13, ISSN 0151-9107

Breck, D.W. (1974). Zeolite Molecular Sieves: Structure, Chemistry and Use, John Wiley, ISBN 0471099856, New York, USA.

Cañizares, P.; Durán, A.; Dorado, F. \& Carmona, M. (2000). The role of sodium montmorillonite on bounded zeolite-type catalysts. Applied Clay Science, Vol. 16, No. 5-6, (May 2000), pp. 273-287, ISSN 0169-1317

Chartrand, M.M.G. \& Bunce, N.J. (2003). Electrochemical remediation of acid mine drainage, Journal of Applied Electrochemistry Vol. 33, No. 3-4, (March 2003), pp. 259-264, ISSN 1572-8838

Diz, H.R. \& Novak, J.T. (1998). Fluidized bed for the removing of iron and acidity from acid mine drainage. Journal of Environment Engineering, Vol. 124, No. 8, (August 1998), pp. 701-708, ISSN 1943-7870

Evangelou, V.P. \& Zhang, Y.L. (1995). A review: Pyrite oxidation mechanisms and acid mine drainage prevention. Critical Reviews in Environmental Science and Technology, Vol. 25, No. 2, (November 1995) pp. 141-199, ISSN 1064-3389

Feng, D.; Aldrich, C. \& Tan, H. (2000). Treatment of acid mine water by use of heavy metal precipitation and ion exchange. Minerals Engineering, Vol. 13, No. 6, (June 2000), 623-642, ISSN 0892-6875

Genç-Fuhrman, H.; Mikkelsen, P.S. \& Ledin, A. (2007). Simultaneous removal of As, Cd, Cr, $\mathrm{Cu}, \mathrm{Ni}$ and $\mathrm{Zn}$ from stormwater: Experimental comparison of 11 different sorbents. Water Research, Vol. 41, No. 3, (February 2007), pp. 591-602, ISSN 0043-1354

Gibert, O.; de Pablo, J.; Cortina, J.L. \& Ayora, C. (2005). Municipal compost-based mixture for acid mine drainage bioremediation: Metal retention mechanisms. Applied Geochemistry, Vol. 20, No. 9, (September 2005), pp. 1648-1657, ISSN 0883-297

Godelitsas, A. (1999). Transition metal complexes supported on natural zeolitic materials: an overwiew. In: Natural microporous materials in environmental technology, P. Misaelides; F. Macásek; T.J. Pinnavaia \& C. Colella (Eds.), 271-281, Springer, ISBN 97-8079-2358-88-6 Dordrecht, Germany

Hequet, V.; Ricou, P.; Lecuyer, I. \& LeCloirec, P. (2000). Removal of $\mathrm{Cu}^{2+}$ and $\mathrm{Zn}^{2+}$ from aqueous solutions by sorption onto mixed fly ash. Fuel, Vol. 80, No. 6, (May 2001), pp. 851-856, ISSN 0016-2361

Ibrahim, H.S.; Jamil, T.S. \& Hegazy, E.Z. (2010). Application of zeolite prepared from Egyptian kaolin for the removal of heavy metals: II. Isotherm models. Journal of Hazardous Materials, Vol. 182, No. 1-3, (October 2010), pp. 842-847, ISSN 0304-3894 
Ikhsan, J.; Johnson, I.B.B. \& Wells, J.D. (1999). A comparative study of the adsorption of transition metals on kaolinite. Journal of Colloid and Interface Science, Vol. 217, No. 2, (September 1999), pp. 403-410, ISSN 0021-9797

Inglezakis, V.J.; Loizidou, M.D. \& Grigoropoulou, H.P. (2002). Equilibrium and kinetic ion exchange studies of $\mathrm{Pb}^{2+}, \mathrm{Cr}^{3+}, \mathrm{Fe}^{3+}$ and $\mathrm{Cu}^{2+}$ on natural clinoptilolite. Water Research, Vol. 36, No. 11, (June 2002), pp. 2784-2792, ISSN 0043-1354

Jamil, T.S.; Ibrahim, H.S., Abd El-Maksoud, I.H. \& El-Wakeel, S.T. (2010). Application of zeolite prepared from Egyptian kaolin for removal of heavy metals: I. Optimum conditions. Desalination, Vol. 258, No. 1-3, (August 2010), pp. 34-40, ISSN 0011-9164

Jenne, E.A. (1998). Adsorption models. In: Adsorption of metals by geomedia: variables, mechanism and model applications, J.A. Jenne, (Ed.), 11-36, Academic, ISBN: 012-384245-X, San Diego, USA

Johnson, Ch.D. \& Worrall, F. (2007). Novel low density granular adsorbents - Properties of a composite matrix from zeolitisation of vermiculite. Chemosphere, Vol. 68, No. 6, (June 2007), pp. 1153-1162, ISSN 0045-6535

Johnson, D.B. \& Hallberg, K.B. (2005). Acid mine drainage remediation options: a review. Science of the Total Environment, Vol. 338, No. 1-2, (February 2005), pp. 3-14, ISSN: 0048- 9697

Kalin, M.; Fyson, A. \& Wheeler, W.N. (2006). The chemistry of conventional and alternative treatment systems for the neutralization of acid mine drainage. Science of the Total Environment, Vol. 366, No. 2-3, (August 2006), pp. 395-408, ISSN: 0048- 9697

Kannan N. \& Rajakumar, A. (2003). Suitability of various Indigenously Prepared Activated carbons for the adsorption of mercury(II). Toxicological and Environmental Chemistry, Vol. 84, No. 1-4, (December 2003), pp. 7-19, ISSN 0277-2248

Klimkiewicz, R. \& Drąg, E.B. (2004). Catalytic activity of carbonaceous deposits in zeolite from halloysite in alcohol conversions. Journal of Physics and Chemistry of Solids, Vol. 65, No. 2-3, (March 2004), pp. 459-464, ISSN 0022-3697

Meena, A.K.; Mishra, G.K.; Rai, P.K.; Rajagopal, Ch. \& Nagar, P.N. (2005). Removal of heavy metal ions from aqueous solutions using carbon aerogel as an adsorbent. Journal of Hazardous Materials, Vol. 122, No. 1-2, (June 2005), pp. 161-170, ISSN 0304-3894

Mezni, M.; Hamzaoui, A.; Hamdi, N. \& Srasra, E. (2011). Synthesis of zeolites from the lowgrade Tunisian natural illite by two different methods. Applied Clay Science, Vol. 52, No. 3, (May 2011), pp. 209-218, ISSN 0169-1317

Mohan, D., Gupta, V.K., Srivastava, S.K. \& Chander, S. (2001). Kinetics of mercury adsorption from wastewater using activated carbon derived from fertilizer waste. Colloids and Surfaces A-Physicochemical and Engineering Aspects, Vol. 177, No. 2-3, (February 2000), pp. 169-181, ISSN 0927-7757

Mohan, D. \& Chander, S. (2006). Removal and recovery of metal ions from acid mine drainage using lignite - A low cost sorbent. Journal of Hazardous Materials, Vol. 137, No. 3, (October 2006), pp. 1545-1553, ISSN 0304-3894

Mozgawa, W. \& Bajda, T. (2005). Spectroscopic study of heavy metals sorption on clinoptilolite. Physics and Chemistry of Minerals, Vol. 31, (February 2004), pp. 706713, ISSN (electronic): 1432-2021

Nestle, N. (2002). NMR studies on heavy metal immobilization in biosorbents and mineral matrices. Reviews in Environmental Science and Biotechnology, Vol. 1, No. 3, pp. 215225, ISSN 1569-1705

Pereira, F.V.; Alves, L.V. \& Gil, L.F. (2010). Removal of $\mathrm{Zn}^{2+}$ from aqueous single metal solutions and electroplating wastewater with wood sawdust and sugarcane bagasse modified with EDTA dianhydride (EDTAD). Journal of Hazardous Materials, Vol. 176, No. 1-3, (April 2010), pp. 856-863, ISSN 0304-3894 
Peric, J.; Trigo, M. \& Medvidovi'c, N.V. (2004). Removal of zinc, copper and lead by natural zeolite-a comparison of adsorption isotherms. Water Research, Vol. 38, No. 7, (April 2004), pp. 1893-1899. ISSN 0043-1354

Ríos, C.A. (2008). Synthesis of zeolites from geological materials and industrial wastes for potential application in environmental problems. PhD Thesis, University of Wolverhampton, Wolverhampton, England.

Ríos, C.A.; Williams, C.D. \& Roberts, C.L. (2008). Removal of heavy metals from acid mine drainage (AMD) using fly ash, natural clinker and synthetic zeolites. Journal of Hazardous Materials, Vol. 156, No. 1-3, (August 2008) pp. 23-35, ISSN 0304-3894

Ríos, C.A.; Williams, C.D. \& Fullen, M.A. (2009). Nucleation and growth history of zeolite LTA synthesized from kaolinite by two different methods. Applied Clay Science, Vol. 42, No. 3-4, (January 2009), pp. 446-454, ISSN 0169-1317

Ríos, C.A.; Williams, C.D. \& Roberts, C. (2011). Synthesis and characterization of SOD-, CAN- and JBW-type structures by hydrothermal reaction of kaolinite at $200^{\circ} \mathrm{C}$. Dyna, No. 166, (April 2011), pp. 38-47, ISSN 0012-7353

Ruiz, R.; Blanco, C.; Pesquera, C.; Gonzalez, F.; Benito, I. \& Lopez, J.L. (1997). Zeolitization of a bentonite and its application to the removal of ammonium ion from waste water. Applied Clay Science, Vol. 12, No. 1-2, (June 1997), pp. 73-83, ISSN 0169-1317

Saada, M.A.; Soulard, M.; Patarin, J. \& Regis, R. (2009). Synthesis of zeolite materials from asbestos wastes: An economical approach. Microporous and Mesoporous Materials, Vol. 122, No. 1-3, (June 2009), pp. 275-282, ISSN 1387-1811

Santos, S.; Machado, R. \& Correia, M.J.N. (2004). Treatment of acid mining waters. Minerals Engineering, Vol. 17, No. 2, (February 2004), pp. 225-232, ISSN 0892-6875

Song, S. \& Guo, J. (1997). Synthesis of zeolite Y from bentonite. Zeolites, Vol. 18, No. 1, (January 1997), pp. 84, ISSN 1083-2718

Sousa, F.W.; Sousa, M.J.; Oliveira, I.R.N.; Oliveira, A.G.; Cavalcante, R.M.; Fechine, P.B.A.; Neto, V.O.S.; de Keukeleire, D. \& Nascimento, R.F. (2009). Evaluation of a low-cost adsorbent for removal of toxic metal ions from wastewater of an electroplating factory. Journal of Environmental Management, Vol. 90, No. 11, (August 2009), pp. 3340-3344, ISSN 0301-4797

Szostak, R. (1998). Molecular sieves, Blackie Academic and Professional, ISBN 0751404802, London, England

Wattena, B.J.; Sibrella, P.L. \& Schwartzb, M.F. (2005). Acid neutralization within limestone sand reactors receiving coal mine drainage. Environmental Pollution, Vol. 137, No. 2, (September 2005), pp. 295-304, ISSN 0269-7491

Webster, J.G.; Swedlund, P.J. \& Webster, K.S. (1998). Trace metal adsorption onto an acid mine drainage iron (III) oxy hydroxy sulphate. Environmental Science and Technology, Vol. 32, No. 10, pp. 1361-1368, ISSN 0013-936X

Wei, X.; Viadero Jr., R.C. \& Buzby, K.M. (2005). Recovery of iron and aluminium from acid mine drainage by selective precipitation. Environmental Engineering Science, Vol. 22, No. 6, (October 2005), pp. 745-755, ISSN 1092-8758

Zhao, H.; Deng, Y.; Harsh, J.B.; Flury, M. \& Boyle, J.S. (2004). Alteration of kaolinite to cancrinite and sodalite by simulated hanford tank waste and its impact on cesium retention. Clays and Clay Minerals, Vol. 52, No. 1, (February 2004), pp. 1-13, ISSN 0009-8604

Zhao, Y.; Zhang, B.; Zhang, X.; Wang, J.; Liu, J. \& Chen, R. (2010). Preparation of highly ordered cubic NaA zeolite from halloysite mineral for adsorption of ammonium ions. Journal of Hazardous Materials, Vol. 178, No. 1-3, (June 2010), pp. 658-664, ISSN 0304-3894 


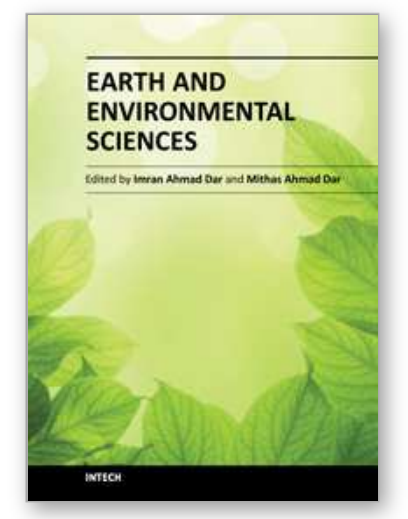

\author{
Earth and Environmental Sciences \\ Edited by Dr. Imran Ahmad Dar
}

ISBN 978-953-307-468-9

Hard cover, 630 pages

Publisher InTech

Published online 07, December, 2011

Published in print edition December, 2011

We are increasingly faced with environmental problems and required to make important decisions. In many cases an understanding of one or more geologic processes is essential to finding the appropriate solution. Earth and Environmental Sciences are by their very nature a dynamic field in which new issues continue to arise and old ones often evolve. The principal aim of this book is to present the reader with a broad overview of Earth and Environmental Sciences. Hopefully, this recent research will provide the reader with a useful foundation for discussing and evaluating specific environmental issues, as well as for developing ideas for problem solving. The book has been divided into nine sections; Geology, Geochemistry, Seismology, Hydrology, Hydrogeology, Mineralogy, Soil, Remote Sensing and Environmental Sciences.

\title{
How to reference
}

In order to correctly reference this scholarly work, feel free to copy and paste the following:

Carlos Alberto Ríos Reyes and Luz Yolanda Vargas Fiallo (2011). Application of Illite- and Kaolinite-Rich Clays in the Synthesis of Zeolites for Wastewater Treatment, Earth and Environmental Sciences, Dr. Imran Ahmad Dar (Ed.), ISBN: 978-953-307-468-9, InTech, Available from: http://www.intechopen.com/books/earth-andenvironmental-sciences/application-of-illite-and-kaolinite-rich-clays-in-the-synthesis-of-zeolites-for-wastewatertreatment

\section{INTECH}

open science | open minds

\author{
InTech Europe \\ University Campus STeP Ri \\ Slavka Krautzeka 83/A \\ 51000 Rijeka, Croatia \\ Phone: +385 (51) 770447 \\ Fax: +385 (51) 686166 \\ www.intechopen.com
}

\author{
InTech China \\ Unit 405, Office Block, Hotel Equatorial Shanghai \\ No.65, Yan An Road (West), Shanghai, 200040, China \\ 中国上海市延安西路65号上海国际贵都大饭店办公楼405单元 \\ Phone: +86-21-62489820 \\ Fax: $+86-21-62489821$
}


(C) 2011 The Author(s). Licensee IntechOpen. This is an open access article distributed under the terms of the Creative Commons Attribution 3.0 License, which permits unrestricted use, distribution, and reproduction in any medium, provided the original work is properly cited. 